\title{
The Syntactic Functions of Relative Clauses in A Game of Thrones Novel
}

\author{
Imelia Anggraeni Deborah $^{1 *}$, Yana Qomariana ${ }^{2}$ \\ English Department, Faculty of Arts, Udayana University \\ ${ }^{1}$ [imeliadeborah@gmail.com], ${ }^{2}$ [yqomariana@gmail.com] \\ *Corresponding Author
}

\begin{abstract}
Abstrak
Penelitian yang berjudul The Syntactic Functions of Relative Clauses in A Game of Thrones Novel ini mengangkat dua pokok masalah yakni; tipe klausa relatif yang ditemukan di novel dan fungsi sintaksis dari klausa relatif yang terdapat dalam novel tersebut. Penelitian ini bertujuan untuk menemukan tipe-tipe klausa relatif yang muncul dalam novel serta menjelaskan fungsi-fungsi sintaksis klausa relatif yang ditemukan. Pengumpulan data diambil langsung dari novel A Game of Thrones yang ditulis oleh $G$. R. R. Martin pada tahun 1996. Data-data yang terkumpul kemudian dianalisis secara deskriptif dan kualitatif. Penelitian ini menerapkan dua teori. Teori utama diusulkan oleh Oshima dan Hogue dalam buku mereka berjudul Writing Academic English (1999). Teori tersebut dipakai untuk mengulas fungsi sintaksis dari klausa relatif. Teori pendukung diusulkan oleh Radford dalam bukunya Transformational Syntax: A Student Guide to Chomsky's Extended Theory (1988). Teori kedua ini digunakan untuk menemukan tipe klausa relatif dalam novel. Penerapan pohon diagram dalam penelitian ini adalah untuk memberikan gambaran jelas mengenai fungsi sintaksis dari klausa relatif. Berdasarkan masalah pertama, penelitian ini menghasilkan bahwa semua tipe klausa relatif ditemukan dalam novel; terbatas, tidak terbatas, dan bebas. Permasalahan kedua menghasilkan bahwa keenam fungsi sintaksis dari klausa relatif semua ditemukan kecuali bagian dari salah satu fungsi yakni klausa relatif pada frasa kualitas tidak ditemukan.
\end{abstract}

Kata kunci: fungsi sintaksis, kata ganti relatif, klausa relatif.

\begin{abstract}
This study is entitled The Syntactic Functions of Relative Clauses in "A Game of Thrones" Novel. It was formulated two problems; types of relative clauses found in the novel as well as the syntactic function of relative clauses found in the novel. It was aimed at finding out the types of relative clauses occurring in the novel and at explaining the syntactic functions found in the novel. The data were collected from $A$ Game of Thrones novel written by G. R. R. Martin in 1996. The data were then analyzed descriptively and qualitatively. There were two theories applied in this study. The main theory was proposed by Oshima and Hogue in their book Writing Academic English (1999). The theory was used as the instrument to answer the syntactic functions of relative clauses. The supporting theory applied in this study was proposed by Radford in his book Transformational Syntax: A Student Guide to Chomsky's Extended Theory (1988). The theory was used to discuss the second problem. The data were presented using tree diagram in order to give clearer images about the syntactic functions. This study showed that based on the first formulated problem the types of relative clauses occurring in the novel were restrictive, non-restrictive and free relative clauses. Based
\end{abstract}


on the second formulated problem, it showed that the functions of relative clauses appearing in the novel were all the six functions but the relative clause in quality phrases did not exist.

Keywords: relative clause, relative pronoun, syntactic function.

\section{Background}

In using grammar, it is a must to know what particles create sentences since grammar greatly deals with sentences.

The most important particle of a sentence is a clause. A clause may be an independent clause, or a dependent clause. In terms of the dependent clause, the clause can be differentiated based on their grammatical functions as nominal clause, adverbial clause, and relative clause (Leech, 1983: 211). Oshima and Hogue (1999: 209) say that a relative clause is a dependent clause that functions as an adjective; it modifies a noun or pronoun. For this reason, a relative clause is also similarly known as an adjectival clause.

A relative clause is introduced by its relaters. There are two types of relaters; relative pronoun and relative adverb. The relative pronoun consists of who, whom, whose, which, and that. On the other hand, relative adverbs consist of where, when and why. Quirk et al $(1985,366)$ point out that a relative clause has two types namely restrictive relative clause and non-restrictive relative clause. The semantic relation between a clause and its relater may be either restrictive or non-restrictive.

A formal distinction between a restrictive and non-restrictive relative clause is found sporadically across languages or only an intonational distinction where the relative clause follows the head noun (Comrie, 1989: 139). Persian is a language with a formal distinction which requires the suffix $-i$ on the head of a restrictive relative, but not on the head of a non-restrictive (Comrie, 1989: 139). On the contrary, the semantic distinction applies equally to prenominal adjectives in English (Comrie, 1989: 139).

Therefore, in English there is no such an affix or a formal distinction to mark whether a relative clause is restrictive or the opposite. Apart from the types, Oshima and Hogue (1999: 212) state that in each different kind, the relative pronoun has a different function.

This study was interesting since there is still confusion among English learners in using relative clauses. Through the discussion of this study, it was expected that the use of relative clauses would be clearer and easier to apply.

\section{Problems of the Study}

a) What types of relative clauses were found in A Game of Thrones novel?

b) What syntactic functions of relative clauses were found in A Game of Thrones novel?

\section{Aims of the Study}

a) To find out the types of relative clauses in the novel $A$ Game of Thrones

b) To explain the syntactic function of relative clauses in the novel $A$ Game of Thrones

\section{Research Method}

A research method deals with the methods used in analyzing this study. There were four aspects discussed in this research method section; data source, method and technique of collecting data, method and technique of analyzing data and method and technique of presenting analysis. 


\subsection{Data Source}

The data of this study were directly taken from the novel A Game of Thrones by George R. R. Martin. This novel was published in 1996 in the United States by Bantam Books. This is one of the seven books under the name $A$ Song of Ice and Fire. This novel has been made into TV series and has become the most popular TV series since its first series of publication. The novel was chosen because the story is interesting and it contains many forms of relative clauses which are very suitable for this study.

\subsection{Method and Technique of Collecting Data}

The data were collected by applying the documentation method. Documentation deals with books or library research. It would only greatly work on reading and examining documents needed for a particular research.

There were some techniques applied. First, the whole novel was read carefully in order to find sentences or clauses containing relative clauses. Next, the collected data were quoted and selected based on the problems being discussed. Finally, the relative clauses were classified in accordance with their types and grammatical functions.

\subsection{Method and Technique of Analyzing Data}

The collected data were analyzed based on the adopted theories. The results of analysis were delivered qualitatively and descriptively. Prior to analyzing the data, there were some steps needed to get proper data.

After all the data were found, they still had to be classified. This classification would involve reduction, to reduce false data or improper data. After that, there was substitution, substituting the reduced data if needed. Finally the data were available for analysis.

In analyzing the data, there were some techniques applied. First, the data were put and classified in accordance with their types; therefore, it would be easier to analyze them. Next, the grammatical functions were described and explained in detail using tree diagram in order to get a clear image of the grammatical functions of the collected sentences or clauses.

\subsection{Method and Technique of Presenting Analysis}

The analyzed data were presented in formal and informal methods. In presenting the data analysis, this study was strengthened by the presence of tree diagrams. The data were analyzed using tree diagram in order to give a clear image and understanding of the problems being discussed. A model given by Van Valin in his book An Introduction to Syntax (2004) was used as the instrument to give a clear image of the data being analyzed using tree diagram. For further explanation, see the tree diagram below:

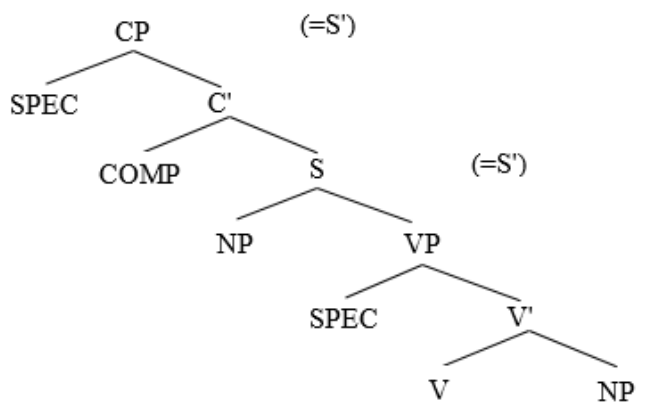

The provided tree diagram which gives clear images of the data being analyzed is called as formal way. It gives the clarity of the constituency and the structure of the English X-Bar theory in general. It could be, then, used to draw English relative clause within the Complementizer Phrase (CP). Furthermore, after the data were drawn onto the tree diagrams, they would be described and explained descriptively in 
order to give full understanding. This way is called as informal method.

\section{Result and Discussion}

\subsection{Types of Relative Clauses}

\subsubsection{Restrictive Relative Clause}

a) This was a place of deep silence and brooding shadows, and the gods who

lived here had no names (Martin, 1996:22)

The construction of the sentence above is as follows:

Sentence $=$ independent clause + relative clause

Relative clause $=$ who + verb + complements

\begin{tabular}{ll}
\hline Independent Clause & \multicolumn{1}{c}{ Relative Clause } \\
\hline This was a place of & \\
deep silence and & who lived here had \\
brooding shadows & no names \\
and the gods & \\
\hline
\end{tabular}

The type of the relative sentence is restrictive which means it is necessarily required to make the clause clear. Consider this sentence if the relative clause is omitted:

a) This was a place of deep silence and brooding shadows, and the gods

It can be clearly seen that if the relative clause is omitted, the dependent clause and the gods who lived here had no names will be incomplete and unclear. Moreover, there is no comma used before the relative clause, which is the characteristic of non-restrictive relative clause.

\subsubsection{Non-Restrictive Relative Clause}

a) Rickon called his Shaggydog, which

Bran thought was a pretty stupid name for a direwolf (Martin, 1996: 78)

The construction of the sentence is as follows:
Sentence $=$ independent clause + relative clause

Relative clause $\quad=$ which + subject

+ verb + complement

Independent Clause Relative Clause

which Bran

Rickon called his

Shaggydog thought was a pretty stupid name for a direwolf

The relative clause is considered non-restrictive since it can be erased. Note the sentence if it is without the relative clause in it:

a) Rickon called his Shaggydog

This sentence seems to be understandable although it does not have the relative clause anymore. The sentence emphasizes the action which Rickon does. He calls Shaggydog, his pet, and the relative clause is only Bran's, Rickon's brother, opinion about the name given to the pet. This opinion is irrelevant with the action which Rickon does. Bran's opinion inflicts nothing to the action which Rickon does, so the relative clause can likely be deleted.

\subsubsection{Free Relative Clause}

a) There are times when you give me cause to wonder whose side you are on (Martin, 1996: 92)

The construction of the sentence is as follows:

Sentence $=$ independent clause + relative clause

Relative clause $=$ whose + noun + subject + to be

\begin{tabular}{ll}
\hline Independent Clause & \multicolumn{1}{c}{ Relative Clause } \\
\hline $\begin{array}{l}\text { There are times } \\
\text { when you give e } \\
\text { cause to wonder }\end{array}$ & whose side you are \\
\hline
\end{tabular}

This kind of type free relative clause is meant for the relative clause which is headless. It does not have main noun. The relative clause whose side you are on 
refers to no one in the sentence. Instead, it refers to the characters which have conflicts in the story. Therefore, even if there is no noun or pronoun modified by the relative clause, the sentence is clear and understandable.

\subsection{Syntactic Function of Relative Clauses}

5.2.1. Relative Clause as Subjects

a) He groped for words that did not come (Martin, 1996: 7)

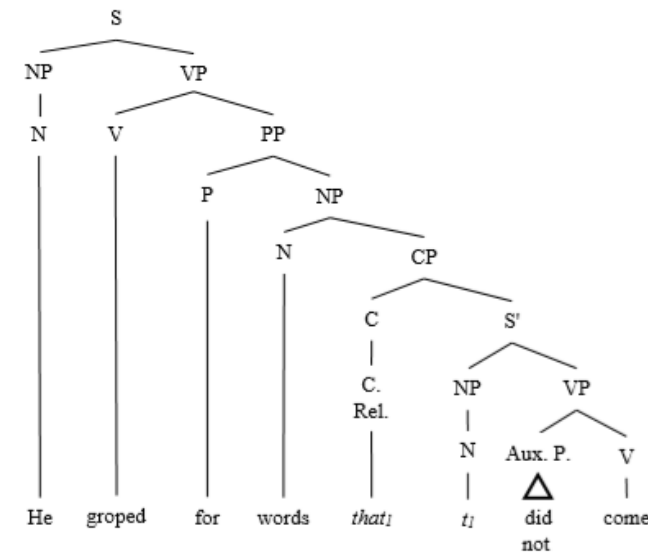

The relative clause above functions as the subject of the noun preceding it, words yet it functions as the direct object within the complex sentence. Consider the complex sentence when separated into two simple sentences:

a. He groped for words

b. Words did not come

The words in the complex sentence is the subject of the verb phrase did not come. The noun words is replaced by the relative pronoun that when both sentences are united. The relative pronoun that also becomes the subordinator of the complex sentence. The relative clause is positioned at the back which means that it is in the final position. The structural relationship corresponds between the object of the main clause and the subject of the relative clause. Subsequently, it builds up an object-subject connection $(\mathrm{o}-\mathrm{s})$.

\subsubsection{Relative Clause as Objects}

a) They found the places that her father had promised. (Martin, 1996: 293)

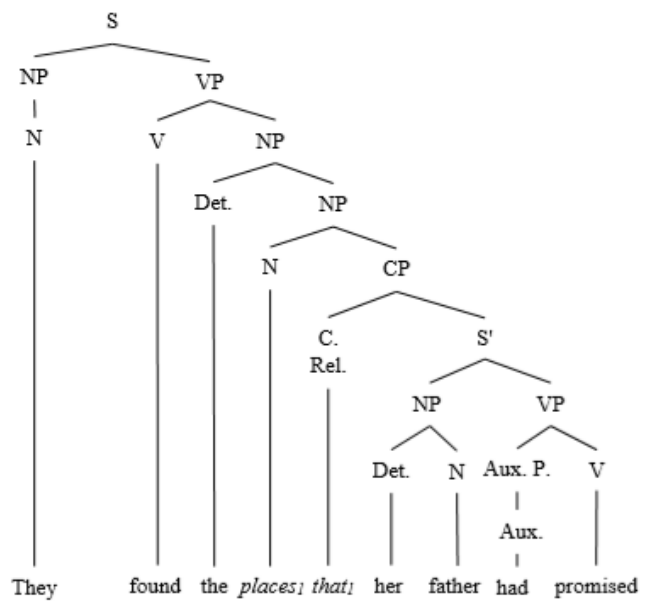

The relative clause functions as the object for the noun preceding it, the places. Consider the complex sentence if separated to clearly see the function of the relative clause:

a. They found the places

b. Her father had promised her the places

The function of the second NP the places is clearly seen from the fragment above. The second NP the places which is replaced by the relative pronoun that is the object of the VP had promised done by the subject of the relative clause, the NP her father. The position of the relative clause is in the final position. The structural connection is between the object of the relative clause and the object of the main clause. This leads to the formation of object-object $(\mathrm{o}-\mathrm{o})$ connection.

\subsubsection{Relative Clause as Object of Preposition}

a) You are tried and found guilty of the crimes for which you stand accused..... (Martin, 1996: 420-421) 


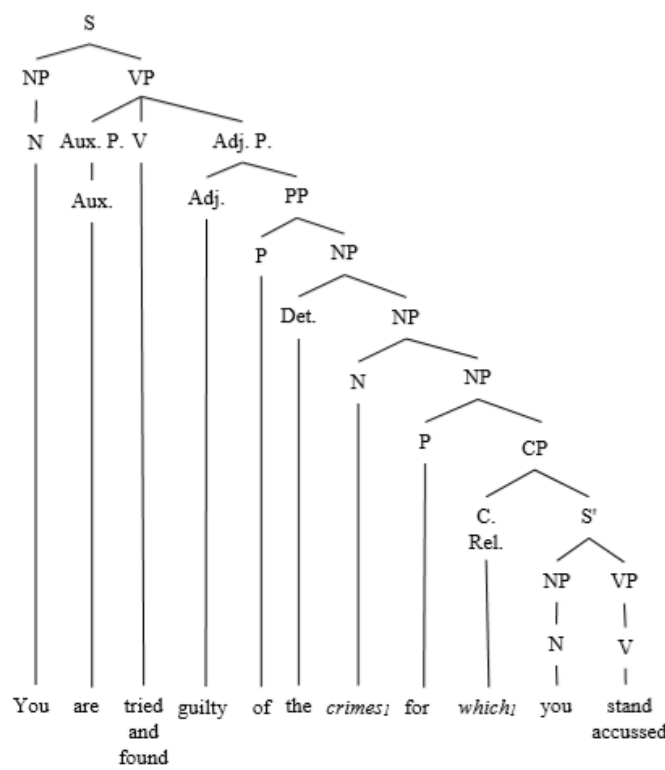

The relative pronoun which appears after the preposition for and it simply makes the relative clause become the object of the preposition. Consider the relative clause if the preposition is moved:

a. You are tried and found guilty of the crimes which you stand accused for

This form is possible in a conversation or in more informal way than that of the first complex sentence.

\subsubsection{Possessive Relative Clause}

a) He rode three passes at Lothor Brune whose armor was drab. (Martin, 1996: 295)

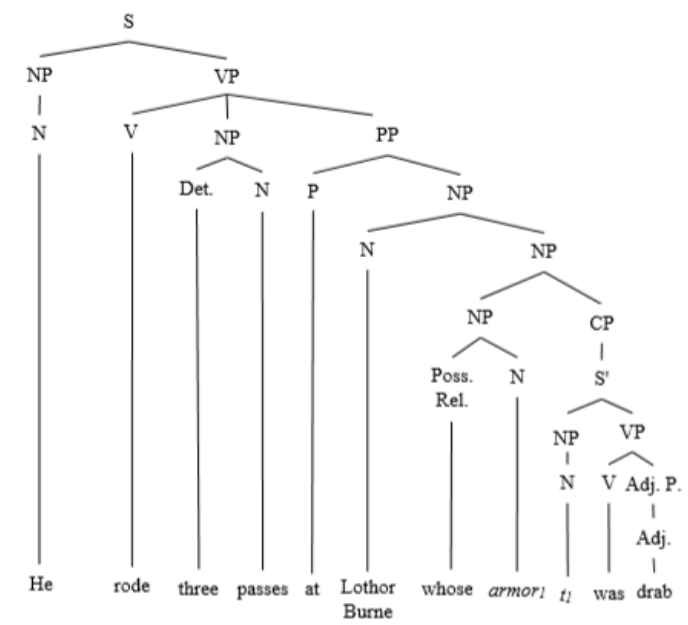

The possessive relative clause whose armor was drab detected within the complex sentence modifies the NP Lothor Brune preceding it. The function of the relative pronoun whose is as the subject of the relative clause. Consider the complex sentence if separated:

a. He rode three passes at Lothor Brune

b. His armor was drab

It is clearly seen in the fragment that the possessive relative pronoun whose functions as the subject of the relative clause since the possessive relative pronoun whose refers to the NP Lothor Brune which is the subject of the clause and it is him who has the armor. The position of the possessive relative clause is in the final position. The structural connection is linked between the object of the main clause and the subject of the relative clause leading to the objectsubject $(\mathrm{o}-\mathrm{s})$ connection.

\subsubsection{Relative Clause in Quantity} Phrases

a) There were quicksands and snakes, none of which stopped Arya. (Martin, 1996: 141)

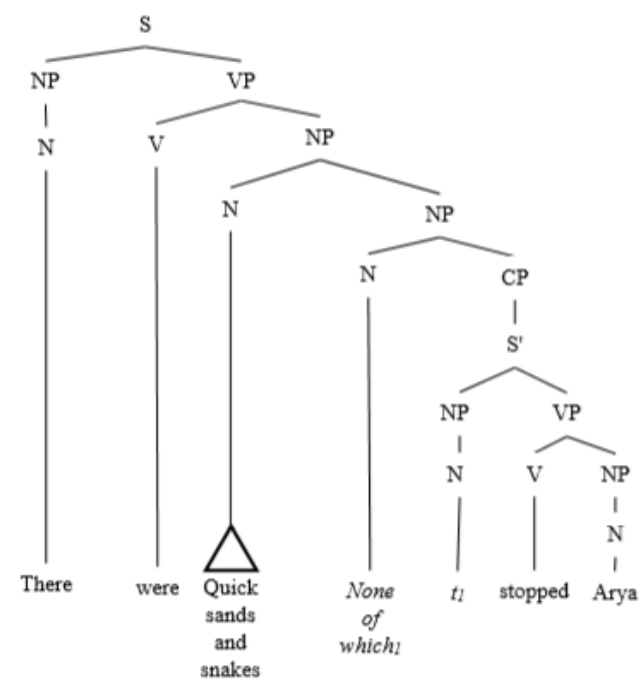

The relative clause detected in the complex sentence above is called Relative Clause in Phrases of Quantity. The relative pronoun is found within a quantity phrase. None of which refers to the nouns before it; quicksands and snakes. The relative pronoun shows that 
none of the things mentioned before stops the subject. Consider the fragment:

a. There were quicksands and snakes watching from the trees

b. They did not stop Arya

\subsubsection{Adverbial Relative Clause}

a) Brandon had been twenty when he died (Martin, 1996: 43)

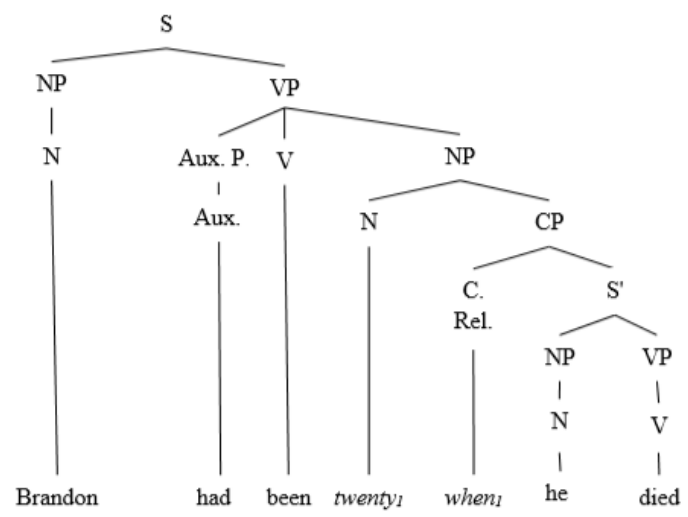

The relative adverb when is found within the complex sentence. It is intended to modify the NP twenty preceding it. See the complex sentence if separated:

a. Brandon had been twenty

b. Brandon died at twenty

When they are combined into one single complex sentence, they need a relativiser and in this case the relative adverb when is used. It is to reduce the repetition of the age twenty as well as to combine both simple sentences.

\section{Conclusion}

The finding of the discussion answering the first formulated problem of this study, which was to find the types of relative clause found in the novel $A$ Game of Thrones was that there are three types of relative clause contained in the novel; restrictive relative clause, nonrestrictive relative clause, and free relative clause. The frequency of presence of each type is different. Restrictive and non-restrictive are the most frequent types used whereas the free type is less frequent.

The second formulated problem was to find the syntactic function of relative clause based on the six functions; as subjects, objects, object of preposition, possessive relative clause, relative clause in quantity and quality phrases, and relative adverb by Oshima and Hogue. They were all found in the novel. However, there is a part of a function which does not appear in the novel; the relative clause in quality phrase. It is only relative clauses in quantity phrases which were found.

Moreover, the most frequent functions appearing in the novel are all of them but the relative adverb and relative clause in quantity phrases. There are a few data for both functions. It is also found that within a complex sentence, the structural relationships linked between the main clauses and the relative clauses were as the subject or object of the relative clause itself as well as the subject or object of the main clause.

The aims of this study were expected to be real since the discussion had done its best to show and discuss each function and type so that the use of relative clause would not be confusing and would be easier to apply.

\section{References}

Comrie, Bernard. (1989). Language Universals and Linguistic Typology. Second Edition. Basil Blackwell, UK. Leech, E. (1983). A Communicative Grammar of English. Kyodo Shing Long Industric Ltd, Singapore.

Martin, George R. R. (1996). A Game of Thrones. Bantam Books, New York.

Oshima, Alice \& Hogue, Ann. (1999).

Writing Academic English. Third Edition. Wesley Longman, New York.

Quirk, Randolph et al. (1985). A Comprehensive Grammar of The 
English Language. Longman Inc., New York.

Radford, Andrew. (1988).

Transformational Grammar. The

Press Syndicate of The University of

Cambridge, UK.

Van Valin, Robert D. (2004). An Introduction to Syntax. The Press Syndicate of The University of Cambridge, UK. 